\title{
Effect of Financial Incentives on Academic Staff Turnover in Public Universities in Kenya
}

\author{
Pascalia Mutiba Chacha \\ MBA Student, School of Business, Laikipia University \\ Thomas Waweru Gakobo \\ Lecturer, School of Business, Laikipia University \\ Isaac Ochieng \\ Professor, School of Business, Laikipia University
}

\begin{abstract}
:
World over, in the higher education sector, the number, quality and effectiveness of the academic staff ensures that the university's goals and objectives are met and that the institutions produce high quality graduates who serve the society at large in different capacities. The academic staffs in universities therefore play a crucial role of imparting the requisite knowledge and skills to these graduates. However, the problem of academic staff turnover in local public universities remains and this threatens the noble role of these institutions in the country's economy. In view of this, the current study sought to investigate the effect of financial incentives on academic staff turnover in public universities in Kenya. The target population of the study were all the teaching staff in Multimedia University of Kenya. 85 respondents were chosen through stratified random sampling. The primary data was collected using a self-administered questionnaire while the "secondary data on the academic staff turnover was collected using a Secondary Data Collection Sheet. The study data was analyzed through both descriptive and inferential statistics with descriptive measures such as frequencies, percentages, mean and standard deviation being used. The Statistical Package for Social Science (SPSS version 23.0) software was used for this purpose. In addition, Pearson's correlation coefficient and regression analysis were the forms of inferential statistics that were used. The study findings were presented in form of tables, graphs and charts. The study findings showed that there was a negative and significant relationship between financial incentives and academic staff turnover in public universities in Kenya $(\beta=-0.718$, p value $=0.000$ ). The study findings will be of great use to the management of public universities in implementing strategies geared towards improving job satisfaction factors so as to reduce on the staff turnover on academic employees.
\end{abstract}

Keywords: Academic staff turnovers.

DOI: $10.7176 / \mathrm{EJBM} / 11-30-13$

Publication date:October $31^{\text {st }} 2019$

\section{Introduction}

Human capital the world's most precious asset for every organization, it ensures the smooth, effective and efficient running of the organization. The knowledge, skills and abilities that human resource processes are the ones that are translated to human capital which is a very valuable asset for the success of every organization (Staw, 2013). Staff turnover is the ratio at which the organization members who leave the organization is compared to that of the people currently in the organization at that specific period. In case a certain position is vacated, the vacancy is either filled by an individual voluntarily or involuntarily and then they are trained to be skillfully effective for the position. Turnover is what this process of replacement is known as. Another term that is used to define the measurement of relations that might lead to an employee leaving the organization and the reasons behind it are termed as employee turnover (Gustafson, 2002). In Africa, in the education sector specifically, the number, quality and effectiveness of the academic staff ensures that the university's goals and objectives are met and that they make a difference in the production of education and to the society at large (Mwadiani and Akpotu, 2012). From this study it is important that public universities come up with strategies to address the problem of employee turnover to be able to address the above Pienaar and Bester (2014) indicates that for the functioning of any university, academic staff plays very crucial roles, to ensure long term education sustainability and quality in the university, there is need for every institution of learning to ensure that their academic staff are well qualified, satisfied and committed to 
the organization. Naris and Ukpere (2015) argues that competitive edge is a demand in every university as it ensures that students and potential employees are attracted to the institution. A case study of South African higher institutions was done, and it was established that academicians leave their higher institution due to lack of competitive edge as shown by about $5 \%$ to $18 \%$ of respondents. Adedoyin (2014) did another research in Nigeria he was looking at the challenge of brain drain that was experienced in Nigeria's Institutes of learning, whereby most of the academicians left the Nigerian higher institution to other small countries such as Ghana and Rwanda, they felt that they received quality pay for the work in education while others opted for options in countries like Britain, America, France and Germany which have the best education institutions in the world. UNESCO Kenya strategy report (2014) in a study conducted in JKUAT on staff retention within the public universities shows that, the social economic and technical development of organizations are greatly influenced by manpower provision and development, through education which is provided by universities. It is important to note that the most specialized and skilled personnel are all products of universities which ensure provision of quality education to its students. Universities are the major storehouses of knowledge globally. A lot of emphasis has been done on advertising university programs to attract new students to pursue studies in different faculties and most of the universities in Kenya have commercialized their services, the universities rely heavily on academic staff for the success of their programmes, with brain drain of academic staff the expertise base in services offered will be eroded (Omamo 2014). A study on financial incentives reveals that most employees leave one employment to another due to a feeling that they are paid less than they are worth (Locke, 2013). A look at our Kenyan Public university indicate, Some universities delay payment of salaries to their academic staff and have a very long procedure to be followed for the payment of cash to be effected, especially to the part time academic staff. Financial incentives represent one of the major causes of high staff turnover rate in many public higher learning institutions in Kenya. Shukla and Sinha 2013 observed that when an employee is paid low with inadequate benefits they feel cheated and will be in a lookout for employers with a better pay somewhere else. When employees find other places that pay them much better than the organization they currently work for, they use this as the major reason to leave the organization. It is therefore critical to note that employees' organizational membership outcomes are determined by the pay they receive.

\section{Literature Review:}

This study reviews empirical studies on job satisfaction factors that include financial incentives, working conditions, employee relations with supervisors, and job security. The factors that lead to job satisfaction are pay, promotion; work itself, supervision, relationships with co-workers and opportunities for promotions (Opkara, 2012). Pay is the most important factor out of all the factors. Hale (2015) indicates that equity based compensation and performance have a very significant relationship with each other. The retention and attraction of employees is greatly influenced by compensation. Rajhans (2012) asserts that, social factors are equally important in motivating workers. Therefore, the need for adequate remuneration system cannot be overstated. An organization's goals can be well achieved, increase the employee's morale and disrupt laxity through administering the employees with an effective and satisfactory wage and salary payment system in the organization. An organization's level of compensation greatly affects the satisfaction of employees in their jobs. Beardwell and Claydon (2014) did a study on how job satisfaction was affected by pay and the findings showed that pay had a significance influenced on job satisfaction of employees. Jain, Sharma and Jain, (2011); Morris (2014) also did a study and found that compensation and performance had a positive relationship with each other. Andrew and Kent (2015) posit that failure in most organizations results from the managers' failing to satisfy their employees, Financial rewards take the forms of: salary, wages, bonuses, pay incentives, medical insurance, paid holidays and recreation and also total remuneration (base pay and contingent pay), (Chiang and Birtch, 2014). According to Gregson (2014), money has always been important to employees. This is because money given to employees portrays how an employer thinks of his/her employees. Employee's massive turnover can be an indicator that something is going wrong within an organization (Karl and Sutton, 2016). Costs related to the staff turnover that include; recruitment costs, training costs, and departmental discontinuity costs, all affect the image and quality of services in the public university. According to Morris (2014) there are different perceptive that financial rewards can be viewed from, reward is a compensation or payment that an organization pays an employees for the use of their skills, time and effort for the benefit of the organization. Employees measure their worth and on how much rewards and compensations they receive in their places of work. Motivating all members of staff is ensured through the use of rewards that are financial and non-financial; ensuring pay promotes team work among employees and effective methods of ensuring employees values are considered through fair pay (Chiang and Birtch, 
2014).Sokoya (2016) did a study on public sector managers that found that job satisfaction was greatly affected by the level of income given to employees in the company.

\section{Methodology:}

This study used both primary and secondary data. The primary data was collected using a self-administered questionnaire. The questionnaire contained 5 Sections. Respondents' demographic profile was covered in the first section while the other sections contained questions based on the study objectives. The secondary data on the academic staff turnover was collected using a Secondary Data Collection Sheet. Questionnaires were applied as the data collection method for the primary data. The researcher first required the respondents to give their informed consent. Once the respondents gave consent, the questionnaires were administered using the drop and pick later method, with a time lapse of one week to enhance the response rate. The main reasons why questionnaires are mostly preferred is due to the fact that they are relatively easy and are cost effective (Mugenda and Mugenda, 2012). The secondary data was extracted from the University's HR records. Before the actual data collection, pretesting of the questionnaire was done. According to Mugenda and Mugenda (2008), a sample of $10 \%$ is adequate for the pilot study. A total of 9 questionnaires was used for the pretesting among academic staff of the University, but who did not take part in the main study. Reliability may be the measure of degree to what an enquiry instrument will yield consistent results and information once recurrent trial runs are done. Reliability during a research is influenced by the random error. Random error is a deviation from the real measurement caused by an ambiguous issue of instructions to subjects, inaccurate coding, interviewer's bias and interviewers' or interviewee's fatigue among others. Random errors will always exist irrespective of the procedures used in a study. Validity is the degree by which the results gotten from the analysis of data represent the purpose of investigation. Validity addresses the accuracy of the data obtained from a study representing the variables of study which the data may be a reflection of the true variables under study. Validity is basically the absence or presence of either systematic or non-random errors in data. Validity is a matter of degree no data can have a perfect validity. To facilitate data analysis, all the questionnaires collected were referenced and the content coded. Data cleaning was then carried out to check for any errors. The study data was analyzed through both descriptive and inferential statistics with descriptive measures such as frequencies, percentages, mean and standard deviation being used. The Statistical Package for Social Science (SPSS version 23.0) software was used for this purpose. In addition, Pearson's correlation coefficient and regression analysis was the form of inferential statistics that was used. The study findings were presented in form of tables, graphs and charts.

\section{Result and Discussion:}

The researcher administered questionnaires to the sample target population of 85 respondents. Out of the administered questionnaires, 66 were completely filled. This gave a return rate of $78 \%$. Therefore, this return rate was significant as per Ndegwa (2016) suggestions that for collected data to be analyzed, the return rate should be $50 \%$ or more.

Table 3 Response Rate

\begin{tabular}{lcc}
\hline Response & Frequency & Percentage \\
\hline Responded & 66 & 78 \\
Not responded & 19 & 22 \\
Total & $\mathbf{8 5}$ & $\mathbf{1 0 0}$ \\
\hline
\end{tabular}

Source: Survey Data (2019)

Mugenda and Mugenda, (2003) say that a response rate of $50 \%$ is sufficient to analyse the report, however response of $60 \%$ and over $70 \%$ is extremely good to arrive at a meaningful generalizations. The figures have no statistical bearing but are just guidelines. From the findings, respondents agreed with statements regarding financial incentives in their organization to a great extent as shown by an average score of 3.87. Respondents agreed that low levels of financial incentives were the main cause of job dissatisfaction in their occupation as expressed by a mean of 4.01, the salary and benefits they received in the organization commensurate with their responsibilities as expressed by a mean of 3.99 , financial rewards provided an important incentive to the respondents in their job as illustrated by a mean of 3.92. This is consistent with the view of (Opkara, 2012) and Hale (2015) who suggest that the factors that lead to job satisfaction are pay, 
promotion; work itself, supervision, relationships with co-workers and opportunities for promotions. Pay is the most important factor out of all the factors.

\section{Conclusion and Recommendations:}

The study found that respondents agreed with statements regarding financial incentives in their organization to a great extent in that; low levels of financial incentives were the main cause of job dissatisfaction in their occupation, the salary and benefits they received in the organization commensurate with their responsibilities, financial rewards provided an important incentive to the respondents in their job. the non-monetary benefits, such as vacation time and medical insurance that they received in the institution enhanced their job satisfaction, academic staff who were hard-working and results-oriented were rewarded financially in the organization and that financial incentives were satisfactorily reviewed from time to time in the organization. Regression analysis results showed that there was a negative and significant relationship between financial incentives and academic staff turnover in public universities in Kenya, implying that better financial incentives would lower academic staff turnover in public universities in Kenya.

\section{References:}

Adedoyin, G. (2014). Labour turnover among university teachers in South Western Nigeria - issues, solutions and lessons. Masters in Commerce Thesis, Obafemi Awolowo University, Nigeria.

Andrew, D., \& Kent, A. (2015). The impact of perceived leadership behaviors on satisfaction, commitment and motivation. International Journal of Coaching Science, 1(1), 35-56.

Bassett, N., \& Lloyd, G. (2015). Does Herzberg's motivation theory have Staying power? Journal of Management Development, 24(10), 929-943.

Beardwell, J., \& Claydon, T. (2014). Human Resource Management. A contemporary Approach. London: Prentice Hall.

Brockner, J. (2014). Self Esteem at Work: Research, Theory and Practice. Lexington, MA: Lexington Books.

Chiang, F., \& Birtch, T. (2014). Taxonomy of Reward Preference: Examining Country Differences. Management Leadership, 11(3), 357-375.

Daneshfard, C., \& Ekvaniyan, K. (2012). Organizational Commitment and Job Satisfaction in Islamic Azad University. Business \& Commerce, 17(2), 21-28.

Dell, B., Holleran, S., \& Ramakrishnan, R. (2002). Sample Size Determination. Human Resource Journal, 43(4), 207-213.

Eyupoglu, S., \& Saner, T (2017). Job Satisfaction: Does Rank Make a Difference? African Journal of Business Management, 3(10), 609-615.

Folami, L., \& Bline, D. (2012). Relationship among Job Satisfaction, Task Complexity and Organizational Context in Public Accounting. International Review of Business Research Papers, 8(4), $207-$ 224.

Gachanja, D. (2014). Workers Motivation and Labour Turnover among sales agents: A study of British American Insurance Company in Kenya. Unpublished MA Project, University of Nairobi.

Greenberg, J., \& Baron, R. (2014). Behavior in Organisations. New Jersey: Prentice - Hall Inc.

Gregson, T. (2014). The Separate Constructs of Communication Satisfaction and Job Satisfaction. Educational \& Psychological Measurement, 51(1), 131-39.

Gupta, N., \& Shaw, J. (2011). Pay fairness and Employee outcomes: Exacerbation and attenuation effects of financial needs. Journal of Occupational and Organizational Psychology, 74(3), 22-34.

Gustafson, T. (2002). Academic Staff Turnover in Universities. Education Journal, 12(4), 23-54.

Hackman, J., \& Oldham, G. (2015). Development of the Job Diagnostic Survey. Journal of Applied Psychology, 60(5), 159-170.

Hale, J. (2015). Strategic rewards: Keeping your best talent from walking out of the door. Compensation \& Benefits Management, 14(3), 39-50.

Heery, C. (2015). Employee turnover: a study of private clubs in the United States of America. International Journal of Contemporary Hospitality Management, 14(3), 106-113.

Herzberg, F. (1966). Work and the Nature of Man. Cleveland: World Publishing Co.

Jain, S., Sharma, S., \& Jain, R. (2011). Job Satisfaction in Banking: A Comparative Study of Private and Public Sector Banks. International Journal of Science \& Technology, 2(1), 40-48.

Karl, J., \& Sutton, G. (2016). Job Values in Today's Workforce: A Comparison of Public and Private Sector Employees. Public Personnel Management, 27(1), 515-528. 
Khatri, N., Fern, C., \& Budhwar, P. (2016). Explaining employee turnover in an Asian context. Human Resource Management Journal, 11(1), 54-64.

Kothari, C. (2004). Research Methodology: Methods and Techniques (2 ${ }^{\text {nd }}$ Ed.). New Delhi: New Age International (P) Limited.

Kotler, P. (2005). Marketing Management. New Delhi: Thomson Press Ltd.

Kusluvan, S. (2013). Multinational enterprises in tourism: A case study of Turkey. Unpublished doctoral dissertation, Strathclyde University, Glascow.

Leblebici, J. (2012). The effect of workplace quality on employee productivity: A case study of a foreign private bank in Turkey. International Journal of Business and Management, 19(4), 43-49.

Levene, C. (2011). Understanding the Research Process and Methods: An Introduction to Research Methods. Cairo: Acts Press.

Lincoln, J. (2016). Employee Work Attitudes and Management Practice in the U.S and Japan: Evidence from a large comparative study. California Management Review, 10(3), 89-106. Locke, E. (2013). The Nature and Cause of Job Satisfaction, in M.D. Dunnette (ed.), Handbook of Industrial and Organizational Psychology, Rand McNally, Chicago: 1297-1349.

Locke, E. (1976). Training them young is the way to up the skills base, Sunday/Business Times, 29 June, page 26.

Luthans, F. (2011). Organizational Behavior. New York: McGraw-Hill

Maori, E., Nandi, T., Thuo, E., \& Wanyonyi, E. (2012). Influence of occupational health and safety programmers on performance of manufacturing firms in Western Kenya. Unpublished thesis, Maseno University.

Maurice, A. (2016). Happy Workers Miss Fewer Days. Journal of Causality Risk \& Benefits, 10(2), 13-18.

McDonald, B., \& Hutcheson, D. (2013). Employee Loyalty and Commitment Directly Impact the Bottom Line. International Business Journal, 11(2), 18-27.

McGregor, D. (2016). The Human Side of Enterprise. New York: McGraw Hill.

Michael, S. (2011). Using Motivational Strategy as Panacea for Employee Retention and Turnover in Selected Public and Private Sector Organisations in the Eastern Cape Province of South Africa. Master of Commerce Thesis, University of Fort Hare.

Morris, M. (2014). The public school as workplace: The principal as a key element in teacher satisfaction. Los Angeles: California University Press.

Mugenda, O., \& Mugenda, A. (2012). Research Methods Dictionary. Nairobi: Acts Press.

Mwadiani, M., \& Akpotu, N. (2012). Academic Staff Turnover in Nigerian Universities. Education Journal, 12(4), 23-54.

Nachmias, C., \& Nachmias, D. (2008). Research Methods in Social Science (5 ${ }^{\text {th }}$ Ed.), London: St. Martin Press, Inc.

Naris, S., \& Ukpere, W. (2015). Developing a retention Strategy for qualified Staff at the Polytechnic of Namibia. Business Papers and Reports. No. 26.

Nguyen, A., Taylor, J., \& Bradley, S. (2013). Relative Pay \& Job Satisfaction, Some New Evidence. MPRA Paper No 1382.

Omamo, A. (2014). An Analysis of factors used to attract and retain employees in a competitive environment: A case study of presenters in selected FM Radio Stations operating in Nairobi. Unpublished MBA Project, University of Nairobi.

Opkara, J. (2012). The Impact of Salary Differential on Managerial Job Satisfaction. A Study of the Gender Gap and Its Implications for Management Education and Practice in a Developing Economy. Journal of Business in Developing Nations, 2(1), 65-92.

Orodho, J. (2005). Elements of education and social science research methods. Nairobi: Masola Publishers.

Osborn, J., \& Waters, E. (2002). Four assumptions of multiple regression that researchers should always test. Practical Assessment, Research \& Evaluation, 8(2), 1-7.

Padilla, D. (2013). Job satisfaction of vocational teachers in Puerto Rico. The Ohio State University

Park, H., Mitsuhashi, H., Fey, C., \& Bjorkman, I. (2013). The effect of human resource management practices on Japanese MNC subsidiary performance. A practical mediating model. International Journal of Human Resource Management, 14(8), 1391-1406.

Patton, M. (2002). Qualitative Research and Evaluation Methods. Thousand Oaks, CA: Sage.

Pienaar, C., \& Bester, C. (2014). Retention of Academics in the Early Career Phase. SA Journal of Human Resource Management, 6 (2), 32 - 41.

Radivoev, J. (2013). The Retention of Sales Consultants in the Security Industry. Unpublished MBA Thesis, 
University of Johannesburg.

Robbins, S. (2014). Organizational Behavior. (10 ${ }^{\text {th }}$ Eds.). New Jersey: Prentice Hall.

Samuel, O., \& Chipunza, C. (2014). Employee Retention and Turnover: Using Motivational Variables as a Panacea. African Journal of Business Management, 5(8), 410-415.

Sanderson, A., Phua, V., \& Herda, D. (2016). The American Faculty Poll. Illinois: National Opinion Research Center

Saunders, M., Lewis, P., \& Thornhill, A. (2003). Research Methods for Business Students, (3 ${ }^{\text {rd }}$ Ed). Harlow: Pearson Education.

Sokoya, S. (2016). Personal Predictors of Job Satisfaction for the Public Sector Manager. Implications for Management Practice and Development in a Developing Economy. Journal of Business in Developing Nations, 13(3), 78-85.

Sparrow, P., \& Hiltrop, J. (2012). European human resource management in transition. New York: Prentice Hall.

Ssesanga, K., \& Garrett, R. (2015). Job satisfaction of University Academics: Perspectives from Uganda. Higher Education, 50(6), 33-56.

Staw, B. (2013). Psychological Dimension of Organisational Behaviour. New York: Macmillan Publishing Company.

Shukla, Y., \& Sinha, K. (2013). Results of High Turnover in Universities. Education Journal, 12(4), 12-17.

Tettey, J. (2016). Staff Retention in African Universities: Elements of a Sustainable Strategy. Washington, DC: World Bank Publication.

Waswa, F., \& Katana, G. (2014). Academic Staff Perspectives on Operating Beyond Industrial Actions for Sustainable Quality Assurance in Public Universities in Kenya. International Journal of Environment, 4(1), 45-58.

Yousaf, A. (2015). One Step Ahead: Examining New Predictors of Affective and Organisational Occupational Commitment. PhD Thesis, University of Nairobi. 